\title{
On the New Path of College English Teaching under the Background of "Curriculum Ideology and Politics"
}

Fang Wei

Wenzhou City University, Wenzhou 325000, Zhejiang Province, China

Funding: Supported by Zhejiang Radio and TV University 312 Personnel Training Project Funds

\begin{abstract}
Under the guidance of the fundamental task of moral education, the ideological and political concept of curriculum has become an important theoretical support for the implementation of teaching activities in higher education. In the teaching process of various majors and disciplines, teachers should not only comprehensively improve students' professional knowledge and skills, but also comprehensively infiltrate ideological and political education to guide students to establish correct values, political views and moral views, So as to comprehensively promote the healthy development of College Students' ideology. Taking college English teaching as the research direction, this paper explores the path and strategy of College English Teaching Reform under the ideological and political theory of curriculum, so as to provide necessary help for improving the quality of College English teaching and enhancing the comprehensive quality of college students.
\end{abstract}

Key words: "Ideological and political education of curriculum"; College English; Reform in education; Path exploration

Publication date: December, 2020

Publication online: 31 December, 2020

"Corresponding author: Fang Wei, 1362646011@ qq.com

\section{Current situation of College English teaching}

1.1 Teachers' ideological and political consciousness is relatively weak.

At present, the ideological and political level of college teachers needs to be improved. They are lack of ideological and political knowledge reserve, strong awareness of ideological and political education, and have no ability and motivation to infiltrate ideological and political education in the process of English teaching. Therefore, students can not get the education and cultivation of world outlook and values, and they often absorb English culture without thinking. Teachers are the leaders in carrying out ideological and political education. Only by actively learning ideological and political knowledge and establishing correct ideological and political concepts, can teachers play a leading role in creating a strong ideological and political atmosphere in classroom teaching, so as to stimulate students' awareness of learning ideological and political knowledge. Only by changing teaching concepts and combining English teaching with ideological and political teaching can teachers really enhance students' ideological and moral awareness.

\subsection{The content of English textbooks is thin.}

College English textbooks are set in the workplace and life, and the theme is close to real life, but the content is too thin. Each chapter only involves some simple greetings, without more in-depth oral content. In real life, after greeting, people must have a detailed dialogue on life or work, and have an in-depth discussion on specific matters. Only in this way can the communication between the two sides have substantive content and significance. However, the content of in-depth dialogue in College English textbooks is less, and English culture is less introduced. The introduction of English speaking 
countries is too shallow and abstract. As a result, students are unable to make a comparative study of Chinese and Western cultures, thus unable to deeply understand the advantages of the socialist system, and unable to produce deep feelings of home and patriotism.

\subsection{The way of English teaching is too old.}

English teachers in Colleges and universities mostly focus on indoctrination teaching, do not pay attention to innovative education and teaching methods, and rarely carry out English teaching activities. Students can not learn English from the perspective of language as a whole, but can only analyze English from grammar, words, pronunciation and other aspects. Students can not realize the objective laws of language learning, and waste a lot of energy in recitation and memory, unable to learn in the present Understand and use English in real life. Teachers often teach according to the content of teaching materials or syllabus, and don't pay attention to carrying out additional listening teaching or reading teaching. As a result, students can't get access to the latest English materials and don't understand the actual development of English speaking countries. Students can only understand the West with the concept of country, but can't analyze the western society and Western system from the perspective of culture and society Thinking doesn't feel much. In this way, students will not be able to improve their cultural and moral qualities in the process of understanding the west, nor can they realize the profound connotation of the Chinese dream.

\section{College English teaching strategies under the background of "Curriculum Ideology and politics"}

\subsection{Improving "ideological and political conscio- usness" and giving full play to educational function}

Teachers play an important guiding role in the curriculum. If teachers do not have ideological and political awareness, they will not be able to penetrate this concept into the English classroom. At present, most college English teachers believe that college students have grown up, they have the ability of independent thinking and learning, understand what can and why not, so in English teaching, they unconsciously ignore the ideological and political education. Over time, most teachers lose the ability to integrate ideological and political knowledge into English teaching. Therefore, in order to carry out English Teaching under the ideological and political concept of curriculum, first of all, colleges and universities need to improve teachers' ideological and political level through Inner-Party Political Life and ideological and political theory learning, so that teachers can understand that they not only shoulder the responsibility of teaching, but also shoulder the responsibility of educating people. Secondly, schools need to make teachers have a comprehensive understanding of the ideological and political education through training and exchange learning. In this way, teachers can understand the connotation of ideological and political education and their mission, so as to actively study English textbooks and integrate English knowledge with ideological and political knowledge. In addition, to improve teachers' ideological and political awareness, teachers can always adhere to political rules, have the ability of cultural screening, and know how to promote the correct political ideas for students, so as to unite with students to resist the hostile trend of thought and bad culture of the west, resolutely safeguard national interests, and promote the prosperity and stability of our country.

\subsection{Enriching teaching content and building up cultural confidence}

In order to improve the efficiency of English teaching and help students master English knowledge as soon as possible, English textbooks cover not only many English grammar, sentence patterns, but also many Western cultures. Due to the lack of Chinese elements in English textbooks, there are no ideological and political elements such as patriotism and Chinese culture in English syllabus. Therefore, it is very difficult for teachers to use English textbooks for ideological and political education. To change this situation and give full play to the educational effect of English classroom, teachers need to change the traditional syllabus, enrich the teaching content, and integrate patriotism, socialist core values, and traditional Chinese culture into it. For example: Teachers can reasonably prepare some English articles related to Chinese politics, economy and culture according to students' basic English knowledge level, and then carry out English teaching 
according to them, so that students can receive ideological and political education while learning English knowledge. Therefore, in English teaching, teachers can regularly hold debates on Chinese history and traditional culture for students. This can not only enhance students' cultural heritage, but also improve their oral English and listening ability.

\subsection{Applying ideological and political elements to optimize teaching methods}

In terms of teaching methods, teachers should also take ideological and political infiltration as the center and carry out reasonable reform and optimization. First of all, teachers should make good use of information-based teaching methods. Whether it is micro class or online course, they can present the teaching content through video, and teachers can reasonably integrate the content of ideological and political education in the process of video production and design. For example, when choosing situational cases, they can use social news or actual events to lead students to build correct values. Secondly, teachers should make use of practical activities to realize ideological and political infiltration. Teachers can design different practical activities according to students' professional direction. Finally, teachers should also carry out reflection activities, asking students to reflect on their performance in the learning process and ideological and political themes after each unit of study, constantly sublimate and improve students' personality in the reflection diary, and at the same time, exercise students' English writing level.

\subsection{Optimizing the evaluation system and enhancing the ideology}

College English evaluation is mainly based on examination evaluation, and teachers judge students' English level by examination results. Therefore, teachers seldom assess students' oral and reading ability, which is the performance of the imperfect evaluation system. Moreover, they pay too much attention to the knowledge level of students, and ignore the evaluation of students' ideology, which leads to students' shallow thinking and negative impact on society and the understanding of the development of China and the country is not clear enough. In study and work, it is easy to fall back because of setbacks and difficulties, and lose the fighting spirit and hope to face life bravely. Therefore, teachers should combine knowledge examination with thought examination to form a comprehensive evaluation system. They should not only urge students to learn knowledge, but also urge students to improve their own ideological level, understand and learn more beneficial thoughts, so as to avoid serious mistakes caused by bad social thoughts.

\subsection{Carrying out extracurricular activities and enhancing moral standards}

Colleges and universities generally hold largescale English speech or writing competitions, but the participants are only a small number of students with high English level, and many students with average English level do not have the opportunity to participate in these English activities. Therefore, teachers can organize some English competitions within the scope of class or grade, set more attractive prizes, so that every student has the opportunity to participate in them. Competition is not only a learning incentive for students, but also a moral test. Only when students participate in the competition honestly and trustworthy, and win prizes with their own strength, can they feel the joy of the competition. If they cheat in order to get the competition place or prizes, it means that the ideological and moral standards of students are not high enough. Teachers should correct and strengthen the moral cultivation of students in time. Teachers can also hold English corner, English lectures and other extracurricular activities to mobilize students' learning enthusiasm, promote students to carry out extensive and profound exchanges, let students learn each other's excellent ideological quality and moral concept, so as to improve their personal ideological and moral level, which plays an important role and significance for students' life growth, and helps to cultivate students into law-abiding and moral students Talents in the new era.

\section{Conclusion}

To sum up, ideological and political education plays a promoting role in College English teaching, so that teachers can attach importance to moral education of students while imparting English knowledge, so that students can learn ideological and political knowledge and understand the connotation of ideological and political education. College English teachers integrate ideological and political elements into English teaching by expanding their own ideological and 
political knowledge reserves, enriching teaching contents, innovating teaching methods, establishing a comprehensive evaluation system, and carrying out English extracurricular activities, which not only enriches students' learning experience, but also greatly enriches the educational connotation of college education, and realizes the goal of ideological and political education This paper discusses the educational purpose of "establishing morality and cultivating people". Students also understand the cultural connotation of English knowledge, improve their ideological and moral level, and have a deep understanding of patriotism, so as to wholeheartedly support the socialist system, strive to become valuable and thoughtful high-level talents, and make contributions to the society and the country under the guidance of the party.

\section{References}

[1] Wang ZQ. Research on ideological and political education in College English teaching under the background of "curriculum ideological and political" reform $[\mathrm{J}]$. Chinese Journal of Multimedia and Network Teaching (Zhongxu), 2019 (2).

[2] Zheng GF. Practice and thinking of curriculum ideology and politics in College English teaching reform [J]. Science and Technology Information, 2019,17(11).

[3] Guo YJ. Research and practice of College English teaching reform from the perspective of curriculum ideology and politics [J]. Journal of Hubei Open Vocational College, 2020, 33(21): 85-87. 